\title{
POISONOUS AND POTENT SUBSTANCES UNDER THE ARTICLE 321 OF THE CRIMINAL CODE OF UKRAINE: LEGAL AND MEDICAL ASPECTS OF TERMINOLOGY
}

\author{
Maryna Bondarenko ${ }^{1}$, Olena Kovalenko ${ }^{2}$ \\ ${ }^{1}$ Postgraduate student, State Research Institute of the Ministry of Internal Affairs of Ukraine, judge of \\ Darnytskyi district court of Kyiv city, Kyiv, Ukraine, e-mail: mari.serg.bond@gmail.com \\ ${ }^{2}$ Candidate of Medical Sciences, associate professor of the State Institution, Dnipro State Medical \\ University, Dnipro, Ukraine, e-mail: helena.j.kovalenko@gmail.com
}

Abstract. This article provides brief information about the legal and medical aspects of the terminology. As for the legal aspect of the matter, such a subject of the crime under Art. 321 of the Criminal Code of Ukraine as poisonous (drastic) substances has been revealed in conjunction with the medical aspects of poisonous and drastic substances. The basic concepts of toxicology have been also revealed, modern classifications of poisonous and drastic substances have been given. Possible threats to the human body from exposure to poisonous and drastic substances, criteria for their evaluation to prevent the occurrence of undesirable toxic effects on the human body have been shown. The purpose of the article is to study the legal and medical aspects of terminology on poisonous and potential substances in accordance with Article 321 of the Criminal Code of Ukraine. The author used system method of scientific research, as well as method of analysis and synthesis. The urgent need for further study of this issue by representatives of various sciences has been proved. Interdisciplinary cooperation will contribute to the harmonization of the relevant provisions of criminal law. Within the framework of an interdisciplinary approach, the interaction among physicians, toxicologists, and clinical pharmacologists will promote better diagnostic, treatment, and prevention of these clinical conditions, increase the safety of poisonous and drastic substances use, and prevent serious consequences for human health.

Keywords: poisonous substances, drastic substances, toxicology, classification of substances, effect on the human body.

JEL Classification: I18, K14

Formulas: 0; fig.:0; tabl.:0; bibl.: 19

Introduction. In Ukraine, with the adoption of the Criminal Code of Ukraine in 2001 [1] (referred to as the Criminal Code of Ukraine, The Code) introduced criminal liability for illegal actions with poisonous and potent substances provided for in Article 321. This norm is actually identical to that that existed in Soviet times under the Criminal Code of Ukraine in 1960 (Art. 229), and not only by description of a socially dangerous act, but also by sanctions [2].

Thus, the last 60years there is a criminal norm to which there is an unreasonably low interest, both on the part of scientists and the legislator, in comparison with the norms establishing criminal liability for drug trafficking offenses.

In addition, as the existence of a certain criminal norm, according to which poison is the subject of a criminal offense, poison is known to criminal law since time not remembered, because history knows many cases of secret poisoning of people. Poison was also a means of execution at the verdict of the court. According to a wellknown fact, the long-greek philosopher Socrates drank a cup of poison at the verdict of the Athenian court, which is also today regarded as committing forced suicide. 
Literature review. There are cases of the use of poisonous or potent substances in the relatively recent past, for example, the so-called. "Assassination with an umbrella" critic of the communist regime of G. Markov, committed September 7, 1978 in London. The criminal case of the late 1980s, which was investigated in Kyiv and was called "Ivanyutin's affairs - Maslenko - Matsybory" was resonant. In this case, 40 episodes of poisoning committed by representatives of the same family were proved, of which 13 were fatal. The largest number of poisonings that caused the death of the victims, namely nine and twenty episodes of the attempted murder was personally committed by T. A. Ivaniutina, who was sentenced to death (execution). The offences were committed using the Clerical Fluid, which is a highly toxic solution based on tally compounds.

Over the past twenty years, it is worth mentioning the following well-known cases with the use of toxic substances themselves: "The Tragedy of Nord-Ost" (2002), "Terrorist Act in Bes lan" (2004), "Poisoning of Sergei Skripal" (2018), "Poisoning of Alexei Navalny" (2020) and others.

Aims. The purpose of the article is to study the legal and medical aspects of terminology on poisonous and potential substances in accordance with Article 321 of the Criminal Code of Ukraine.

Methods. The author used system method of scientific research, as well as method of analysis and synthesis.

Results. The study of the issue of poisonous (potent) substances remains relevant at the moment, since the demand for these substances as an object and means of committing a criminal offense does not fade at all, but only strengthens, given the spread of their use during the war.

1. Poisonous and potent substances in criminal law (Art. 321). Article 321 of the Criminal Code of Ukraine over the past twenty years of its existence has endured changes, but mostly they concerned the sanctions of this article [3] The legislator took such a step to cover the use of this norm in more cases of illegal actions with poisonous drugs that were mistakenly considered unpuned at that time, namely with such a poisonous drug as Tramadol, which a year later was already classified as a narcotic, that is, it is no longer the subject of this crime [4].

In this norm, there is also a clarification to poisonous or potent substances, namely that they are "not narcotic or psychotropic or their analogues", and this, in our opinion, is superfluous, does not contribute to the effective use of this norm, such clarification only depresses the value of substances, and thus does not specify them for the needs of this norm, that the concept of "substance" is end-to-end for a special part of the Criminal Code, in particular, the concept of "poisonous substance", "potent substance" is contained in other articles of the Code: they may be the subject of smuggling (Art. 201);

Poisonous (potent) substance can be the subject of a criminal offense, as in the mentioned Art. 321 of the Code, and a means of its commission.

The draft Criminal Code of Ukraine (control text as of March 29, 2021), in particular, in Article 1.3.1 (meaning of the main terms) proposes to consolidate the definition of the concept of "generally dangerous way", that is, a way that causes 
harm or creates a threat of harm to an undetermined number of people, including the use of toxic substances [5].

Thus, according to the content of the latest scientific study on custommadekillings, it is believed that in some cases, the method of committing murders to order is chosen with such a calculation that it is both a way of hidingthem. [6].

In addition, on the basis of the Law of Ukraine "On Amendments to Certain Legislative Acts of Ukraine on the Implementation of Norms of International Criminal and Humanitarian Law", adopted by the Verkhovna Rada of Ukraine on May 20, 2021, The Criminal Code of Ukraine is supplemented, including by the new Article 438-3 "War crimes related to the use of prohibited means of warfare", the Note contains a caveat that for the purposes of this article, the means of warfare prohibited by international humanitarian law must include the use, in particular, of poison or poisonous weapons; suffocating, poisonous or other similar gases and any similar liquids, materials or means, etc.

Therefore, these terms are used by the legislator, and the content is not disclosed.

At the same time, it should be noted that Article 321 is a norm with a blancet disposition, that is, to clarify all the signs of which it is necessary to apply to other regulatory legal acts, other areas of law, not criminal accordingly.

However, the criminal law on the content of Art. 321 of the Code distinguishes toxic substances from potent substances, the same applies to medicines under this article, although the legislation of Ukraine does not contain certain definitions of "poisonous substance"/"potent substance", and their types/classifications are absent.

Laws that mention poisonous (potent) substances provide only certain restrictions on transportation, prohibition of sale, certain rules for handling them, etc.

List of hazardous properties and instructions for control over cross-border transportation of hazardous waste and their disposal/removal (developed in accordance with the Regulation on control over cross-border transportation of hazardous waste and their disposal/removal, approved by the Resolution of the Cabinet of Ministers of Ukraine of July 13, 2000 No. 1120 [7] contains the following definition of poisonous (potent) substances: "substances or wastes that, by entering the body through the respiratory, digestive or through the skin, can cause the death of a person or havea strong negative impact on it" (p. 6.1) [8].

The legal encyclopedia contains a similar definition of the general concept of "poisonous (potent) substances", which corresponds to p. 6.1 of the mentioned List of the Ministry of Ecology and Natural Resources of Ukraine [9].

One scientific and practical commentary of the Criminal Code of Ukraine contains the following information. Toxic substances are poisons, toxins (combat, medicinal, agricultural and others), which, getting into the human body through the respiratory system, digestion or through the skin, can cause death of a person or psychoneurological disorder, respiratory or cardiovascular function, kidney damage (nephropathy) or liver (hepatopathy), etc. They can be mineral (mouse, strychnine, mercury and sulema, synylic acid and other cyanides, pesticides, etc.), vegetable (poison isolated from the flycatcher, pale toadstle, etc.), animal (snake venom and 
poison produced by arthropod animals) or mixed or artificial (chemical) origin. Potent substances are medicinal, household, industrial and other chemicals that can harm a living organism [10, p. 638]. These include, in particular, aminazine, biseptol, grosseptool, erythromycin, eferalgan, camphor, corvalol, nistatin, nitroglycerin, novocaine, sulfadimezin, tetracycline, furatsilina, some insulin and vitamins, nicotine acid, ginseng and propolis efficacy, iodine solution. Potent substances also include acids, alkalis, salt, as well as doping substances [11].

Another edition of the scientific and practical commentary of the Criminal Code of Ukraine on toxic substances (poisons) is understood as substances of plant, animal and mineral origin or products of chemical synthesis in a solid, powdered or other state, which, in a combination of their inherent properties, create or can pose a danger to humans, the environment, animals and those in need of sleepthese methods, conditions and means of handling them, since their entry into the human body, even in insignificant doses, causes severe poisoning (acute or chronic) or death. For its purpose and features of use, toxic substances are divided into: medical poisons used by chemical enterprises during the manufacture of poisonous drugs (atropine sulfate, snake venom, purified bee venom, strychnin, sulema, vaccine-producing strains, antibiotics, vitamins); professional poisons used in the chemical industry and in other production processes (acetic acid anhydrid, salt cianide, metal mercury and its salts, mouse salts, barium, vatadium, bruceil, hydrogen sulpice, sulfur ether, methyl alcohol, etc.); combat poisonous substances. Potent substances (synthetic or natural origin, including plants) are divided depending on their scope into potent drugs and other substances used in chemical and other industries [12].

The main difference between these definitions is that in one case the focus is on their danger and the consequences of exposure, in the other - more attention is paid to their possible classification by purpose and characteristics.

Although to prosecute a person for illegal actions with such substances under Art. 321 of the Criminal Code of Ukraine, it is important not only to clarify the content of these terms, but also to the criteria for their delineation, which obviously have a different effect on the human body - from simply harmful to impressive with inevitable and irreparable consequences. In turn, the consequences of harm to public health should be reflected in the qualifications of actions, the gradation of possible punishment, taking into account the degree of public insecurity and the harm that was caused. The issue of weight/quantity of such substances is also important for law enforcement practice, since parts 3 and 4 of this Article provide for signs that qualify and especially qualify this offense - "large size", "especially large size".

Therefore, in such hopeless in terms of legislative regulation, so to speak, salvation should be sought in the science of criminal law. However, the science of criminal law has no thorough research on this issue, there is only one dissertation, which was the first on this topic, the successful defense of which took place recently. At the same time, the co-author of this article is convinced that this dissertation study is not enough, this was only the beginning in the study of this issue.

Due to the similarity of regulatory areas and the general danger from toxic substances, which contain references as a crime not only in Article 321 of the 
Criminal Code ofUkraine, there is confusion in the field of protection of a specific norm of certain social relations [13].

The best way to demonstrate the effectiveness of a certain norm is the judicial practice of its application. Thus, according to the content of selectively selected sentences under Art. 321 of the Criminal Code, adopted during the period of ten years 2007-2016, there was a variety of poisonous and potent substances that were the subject of this crime.

It should be noted the following features: in sentences the most frequently distinguishable substance was poisonous or potent; qualifications and punishment were not affected when the same substance was in grams or in tens of liters; the consequences of the offense were not established, since this is a norm with a formal composition, which led to the conviction of persons for actions with substances common in everyday life in small quantities, which hardly required the use of a criminal-legal mechanism for the state's response to such actions.

Generally, it should be noted that the subject of the crime under Art. 321 of the Criminal Code of Ukraine were the following substances: mercury; methanol used to make surrogate alcohol; pesticides, herbicides, insecticides; sodium nitrite, cadmium compound, nickel compound, zinc phosphide; toxic chemicals of groups of organochlorine and organophosphate pesticides used in agriculture, etc. Therefore, the list is quite diverse.

At the same time, it is necessary to create and adhere to a unified legal terminology regarding the subject of crime, which would be based on their understanding in the medical and pharmacological spheres, in particular regarding the impressive and harmful effects of poisonous or potent substances on the human body.

Only lawyers are unlikely to cope with this task, so it is necessary to make joint efforts of representatives of various sciences.

2. Some important medical aspects of terminology in toxicology. Toxicology is a section of medical science that studies the physical and chemical properties of toxic substances, their main mechanisms and types of action on the body, as well as studies possible areas of prevention and treatment of poisoning and the possibility of useful for society the use of toxic substances.

By definition D. Bathler, a scientific direction such as general toxicology, aims to study the effects of any pollutant released into the environment, the high concentrations of which in the atmosphere can cause impaired human health [14].

The task of preventive toxicology is to study the possible effects of toxic danger and prevent toxic effects, to develop various directions to protect people from the toxic effects of various chemicals.

Preventive toxicology, as a science, studies the permissible effects of toxic substances on the human and animal organism, develops possible means of prevention of toxic effects in real conditions of people's lives in domestic conditions, enterprises, food industry, etc.

The scientific department of clinical toxicology studies diseases that arise as a result of toxic effects of various chemicals [15]. 
The very concept of "toxicity", from the Latin "toxicus", "poisonous" is an indicator of the ability of a chemical when interacting with the body to show its harmful effects.

There are such concepts as acute and chronic toxicity:

- acute toxicity - occurs when a significant harmful effect or death occurs in a short period of time after the onset of the substance, when used in a single dose, or at one exposure, or several doses in less than a day;

- chronic toxicity - toxicity, when the harmful effect of a substance or mixture of substances is detected over a long period of time (usually on experimental animals, this period is considered to be 3 months or more, sometimes studies last several years, or throughout life).

Potent poisonous substances are substances that are used for economic purposes and when entering the environment as a result of ejection or spillage can lead to air infection in striking and higher concentrations.

Such chemicals are considered poison, which, depending on the dose and concentration, cause harmful effects on the body, and at high doses lead to the death of the body.

Also in modern literature, such concepts as xenobiotics, toxicant, biotoxicant, etc. are often used $[16,17]$.

It is known that on the territory of Ukraine up to fifty percent of the population lives in the zones of those industrial facilities that use toxic substances in their production cycle. According to the international register of six million toxic substances used in industry, agriculture and everyday life, more than 500 substances belong to potent toxic substances. All processes related to the production, storage, transportation and technologies of the use of potent toxic substances have strict regulation of special safety rules and control over their use, but in case of possible violations of control over the technological process or accidents, severe consequences are possible for the body of a person who has fallen into the affected area.

There are many varieties of classifications of potent poisonous substances due to the large number of their chemical structure, physicochemical properties, various types of influence on the body.

Classification of potent toxic substances by type of action:

1. Substances mainly stuffy action: chlorine, trichloride phosphorus, phosgene, sulfur chloride, etc.;

2. Substances mainly general action: carbon monoxide, blue acid, dinitrophoenyl, ethylene chlorhydrin;

3. Substances that have a suffocating and generally destructive effect: acrylonitrile, nitrogen oxides, sulfur anhydrid, hydrogen sulpice, etc.;

4. Neurotropic poisons that affect the generation, conduction and transmission of nerve impulse: phosphorus-organic substances, carbon suil, etc.

5. Substances that have a suffocating and neurotropic effect: ammonia;

6. Substances that violate the metabolism and cell structure: dioxin;

7. Metabolic poisons: methylbromide, methyl chloride, dimethyl sulfate, ethylene oxide, etc. 
Also, potent poisonous substances differentiate by the speed of their action on the body: rapid action, in slowaction, very slow action.

Toxic substances belong to the rapid action group when the symptoms of intoxication occur during the first minute. These include: hydrochloric acid, hydrogen sulphi, carbon monoxide, acrylonitrile, nitric oxides of high concentrations, chlorine in high concentrations, ammonia, organophosphate substances, etc. substances belonging to the group in slow action, when they are intoxicated, cause the development of symptoms within the first hour after contact. phosphorus oxychloride, dimethyl sulfate, nitric oxides, chlorine, methylchloride, ethylene oxide, carbon sulfide, trichloride phosphorus, sulfur chloride, phosgene, ethylene chlorhydrin, etc.

There is also a distribution of potent toxic substances by chemical structure, which include bases, acids of organic and mineral origin, alcohols and aldehydes, phenols, nitrospolica cresoles, amino acids, organophosphate pesticides, organochlorine, mercury pesticides, phenolocytic acid derivatives and others $[18,19$, 20].

According to the degree of toxicity, toxic substances are classified as follows: extremely toxic; highly toxic; highly toxic; moderately toxic; little toxic; practically non-toxic.

Important parameters for toxicity indicators are indicators of "dose", "concentration".

Taking into account these classes of toxicity, average death doses/concentrations are established at appropriate values at concentrations in the air $(\mathrm{mg} / \mathrm{l})$ and when entering the human body $(\mathrm{mg} / \mathrm{kg})$ [21-22].

There is also a distribution of toxic substances by selective action (this distribution occurs at the place of toxic lesion and, accordingly, according to characteristic toxicants):

1. cardiovascular system (plant poisons: aconite, chemerica, lure, etc.; animal poisons: tetrodotoxin; barium salts, potassium);

2. nervous system (psychopharmacological agents: narcotic analgesics, tranquilizers, sleeping pills; compounds of the mouse, manganese, carbon monoxide; carbon monoxide, tetraethylsvine; pesticides; alcohol and its surrogates, hydrocarbons);

3. liver (chlorinated hydrocarbons: dichloroetan, methyl chloride, chloroform, four-chloride carbon, etc.; poisonous fungi: pale toadstool; phenols and aldehydes);

4. Urinary system (compoundsof heavy metals andmouse; pesticides; organic solvents, oxalic acid, ethylene glycol);

5. hematopoiesis system (aniline and its derivatives; nitrite; articulate hydrogen; benzene and its chloride, toluene);

6. respiratory organs, mucous membranes and skin (vapors of concentrated acids and alkas, compounds of heavy metals andmouse).

This classification provides an understanding of the overwhelming selectivity of the action of poisons on individual organs and systems of the body, but does not exclude other clinical manifestations of intoxication [23]. 
Due to the large number of toxic substances, their unecured physicochemical structure, they also cause various mechanisms of negative impact on the human body. This leads to various manifestations of the clinical picture of poisoning. Therefore, several criteria and indicators for assessing the toxicity of harmful substances have been introduced to characterize the toxic action. There is no single criterion for the full characteristics of the toxic action. Most indicators show the ratio of the amount of harmful substance to the volume of air, water, soil mass, mass of an animal or person.

Basic concepts and dose rates in toxicology:

- the degree of toxicity is the dose that has an effect on the body and leads to pathological changes.

- LD - lethal (lethal) doses or concentrations that cause the effect of death of the body. Doses that cause functional changes in the body can be active, threshold or incaestroent doses or concentrations;

- dose - has an expression in units of mass or volume of a harmful substance per unit of animal mass $(\mathrm{mg} / \mathrm{kg}) . \mathrm{mg} / \mathrm{l}, \mathrm{mg} / \mathrm{kg}, \%$, in parts per thousand $(, \mathrm{ppm})$, in parts per million (pastpromille, $\mathrm{ppm}$ ). Dose (concentration) is often displayed in particles from the lethal dose (concentration), for example, (1/2)LD50; (1/20)LD50, etc.;

- the smallest amount (concentration) of a substance that can cause the death of individual organisms is called the minimum lethal dose (concentration) of the substance LDmin (LKmin);

- a dose of a substance, $\mathrm{mg} / \mathrm{kg}$, which causes the death of 50 or $100 \%$ of organisms, respectively, with a single injected into the stomach through the oral cavity - this is the average lethal dose (concentration) when injected into the stomach LD50vn and LD100vn (LK50vn and LK100vn);

- average lethal dose (concentration) when applied to the skin LD50derm and LD100derm (LK50derm and LK100derm) - a dose of substance, $\mathrm{mg} / \mathrm{kg}$, which causes the death of 50 and $100 \%$ of organisms, respectively, with a single application to the skin;

- average lethal dose (concentration) when inhaling dust or gas LD50 and LD100 (LK50 and LK100) - concentration of the substance in the air, mg/m3, which causes the death of 50 and $100 \%$ of organisms, respectively, with a four-hour inhalation effect, etc. indicators.

Norms for the hazard class are calculated according to the following indicators: MPC of harmful substances in the air of the working area, mg/m3; LD when administered into the stomach, $\mathrm{mg} / \mathrm{kg}$; LD when applied to the skin, $\mathrm{mg} / \mathrm{kg}$; $\mathrm{LK}$ in the air, $\mathrm{mg} / \mathrm{m} 3$; Coefficient of possibility of inhalation poisoning; Acute zone; Zone of chronic action - the ratio of the threshold of acute action of a poisonous substance to the threshold of its chronic action, etc.

Possible hazard classes of harmful and poisonous substances are established depending on the above standards and indicators [24-26].

Conclusions. Thus, the analysis of the issues highlighted in our study shows possible threats to the human body from the effects of poisonous and potent substances, the criteria for their evaluation and the need for measures to prevent the occurrence of unwanted toxic effects on the human body. 
We see the urgent need for further research on this issue by representatives of various sciences, in order to harmonize the relevant norms of the criminal law, and doctors, toxicologists, clinical pharmacologists - within the framework of an interdisciplinary approach to the diagnosis, treatment and prevention of these clinical conditions to increase the safety of the use of poisonous and potent substances and prevent severe consequences for human health.

The need for further study, systematization and clarification of concepts of poisonous and potent substances, their dosage of harmful effects on the body in peacetime (in domestic conditions, industrial enterprises, etc.) is shown within the framework of a multimodal approach to improving the safety of use and prevention of severe consequences for human health.

They concluded that there is no distinction between poisonous or potent substances in the criminal law, in fact, there is no same distinction in toxicology, since this degree is determined by the level of doses and concentration of the substance.

In this regard, there is an urgent improvement of the investigated norm of the Code and, possibly, the development of new norms in order to a more personalized approach, taking into account the diagnosis of the severity of toxic action.

Author contributions. The authors contributed equally.

Disclosure statement. The authors do not have any conflict of interest.

References:

1. Bondarenko M. S. (2021). Kryminalna vidpovidalnist za nezakonni dii z otruinymy chy sylnodiiuchymy rechovynamy abo otruinymy chy sylnodiiuchymy likarskymy zasobamy [Criminal liability for illegal actions with poisonous or drastic substances or poisonous or drastic pharmaceutical drugs]. Dysertatsiia na zdobuttia naukovoho stupeniu kandydata yurydychnykh nauk, Kyiv, p. https://dndi.mvs.gov.ua/files/pdf/dissertation_Bondarenko_M_S.pdf [in Ukrainian].

2. Voloshynskyi O. V., Parashchuk L. D. (1999). Posibnyk z viiskovoi toksykolohii [Manual on military toxicology]. Ivano-Frankivsk, p. 176 [in Ukrainian].

3. Zhuikova T. V. (2018). Ekologicheskaya toksikologiya : uchebnik i praktikum dlia bakalavriata i magistratury [Environmental Toxicology: Textbook and Practical Training for Bachelor's and Master's Degrees] / T. V. Zhuikova, V. S. Bezel. M. : Izdatelstvo Yurait, p. 362 [in Russian].

4. Zakon Ukrainy "Pro vnesennia zmin do Kryminalnoho kodeksu Ukrainy shchodo vstanovlennia vidpovidalnosti za nezakonni dii stosovno otruinykh chy sylnodiiuchykh likarskykh zasobiv” vid 05 kvitnia 2007 roku № 875-V [Law of Ukraine "On amending the Criminal Code of Ukraine regarding the establishment of liability for illegal actions with poisonous or drastic substances or poisonous or drastic pharmaceutical drugs" No. 875-V of 5 April 2007], URL: https://zakon.rada.gov.ua/laws/show/875-16\#Text [in Ukrainian].

5. Kozlovska T. F., Nykyforova O. O. (2016) Zahalna toksykolohiia : Teoretychni aspekty [General toxicology: Theoretical aspects] : navchalnyi posibnyk. Kremenchuk : KrNU, p. 150 [in Ukrainian].

Tarasov A.T., Smirnova T.V. (2006). Osnovy toksykolohii [Fundamental concepts of toxicology] Uchebnoe posobie.

M.: Marshrut, p. 160 [in Russian].

6. Kryminalnyi kodeks Ukrainy [Criminal Code of Ukraine], URL: https://zakon.rada.gov.ua/laws/show/2341-14\#Text [in Ukrainian].

7. Kryminalnyi kodeks Ukrainy v redaktsii 1960 roku [Criminal Code of Ukraine as revised in 1960], URL: https://zakon.rada.gov.ua/laws/show/2001-05\#Text [in Ukrainian].

8. Kurliandskiy B. A. (2004). Strategicheskie podkhody k obespecheniyu proizvodstva i ispolzovaniya khimicheskikh veshchestv dlia zdorovya cheloveka [Strategic approaches to ensuring the safety of the production and use of chemical substances for human health] // Rossiyskiy khimicheskiy zhurnal. V., XLVIII, No. 2. P. 8-15 [in Russian].

9. Lopashchuk D. I. (2018). Ubyvstvo, vchynene na zamovlennia: kryminalno-pravova kharakterystyka [Contract killing: criminal and legal characteristics]. Dysertatsiia na zdobuttia naukovoho stupeniu kandydata yurydychnykh nauk, Kyiv, p. 299, URL: https://www.nam.kiev.ua/files/tesis/Lopashuk_diss_1.pdf [in Ukrainian].

10. Naukovo-praktychnyi komentar Kryminalnoho kodeksu Ukrainy [Scientific-practical comment on the Criminal Code of Ukraine] (2017) / D. S. Azarov, V. K. Hryshchuk, A. V. Savchenko [and others]; under general editorship of O. M. Dzhuzha, A. V. Savchenko, V.V. Cherniei. Kyiv: Yurinkom Inter, p. 1104 [in Ukrainian].

11. Naukovo-praktychnyi komentar Kryminalnoho kodeksu Ukrainy [Scientific-practical comment on the Criminal 
Code of Ukraine] (2012) / under editorship of M. I. Melnyk, M. I. Khavroniuk, issue 9, updated and revised. Kyiv: Yurydychna dumka, p. 1316 [in Ukrainian].

12 Naukovo-praktychnyi komentar Kryminalnoho kodeksu Ukrainy [Scientific-practical comment on the Criminal Code of Ukraine] (2018) / under editorship of M. I. Melnyk, M. I. Khavroniuk, issue 10, updated and revised. Kyiv: VD "Dakor', p. 1368 [in Ukrainian].

13. Perelik nebezpechnykh vlastyvostei ta instruktsii shchodo kontroliu za transkordonnymy perevezenniamy nebezpechnykh vidkhodiv ta yikh utylizatsiieiu/vydalenniam, zatverdzhenyi nakazom Ministerstva ekolohii ta pryrodnykh resursiv Ukrainy vid 16 zhovtnia 2000 roku № 165 [List of hazardous properties and instructions for control over transboundary movements of hazardous waste and their utilization/disposal, approved by the Decree of the Ministry of Ecology and Natural Resources of Ukraine No. 165 of 16 October 2000], URL: http://zakon2.rada.gov.ua/laws/show/z0770-00 [in Ukrainian].

14. Polozhennia pro kontrol za transkordonnymy perevezenniamy nebezpechnykh vidkhodiv ta yikh utylizatsiieiu/vydalenniam, zatverdzhene postanovoiu Kabinetu Ministriv Ukrainy vid 13 lypnia 2000 roku № 1120 [Regulation on the control over transboundary movements of hazardous wastes and their utilization/disposal, approved by the Resolution of the Cabinet of Ministers of Ukraine No. 1120 of 13 July 2000], URL: http://zakon2.rada.gov.ua/laws/show/1120-2000-\%D0\%BF [in Ukrainian].

15. Postanova Kabinetu Ministriv Ukrainy "Deiaki pytannia obihu narkotychnykh zasobiv i psykhotropnykh rechovyn» $\begin{array}{lllll}\text { vid } & 04 & \text { chervnia } & 2008 & \text { roku }\end{array}$ № 518 [Resolution of the Cabinet of Ministers of Ukraine "Some issues of narcotic and psychotropic substance trafficking" No. 518 of 4 June 2008], URL: https://zakon.rada.gov.ua/laws/show/518-2008-\%D0\%BF\#Text [in Ukrainian].

16. Proekt Kryminalnoho kodeksu Ukrainy (kontrolnyi tekst stanom na 29 bereznia 2021 roku) [Draft Criminal Code of Ukraine (control text as of 29 March 2021)], URL: https://newcriminalcode.org.ua/upload/media/2021/03/30/kontrolnyj-proekt-kk-29-03-2021-1.pdf [in Ukrainian]. 17. Cherniakov H. O., Kochin I. V., Sydorenko P. I. (2001). Medytsyna katastrof [Disaster medicine], K.: "Zdorovia", p. 348 [in Ukrainian].

18. Ekstremalnaya toksikologiya. Uchebnik pod redaktsiyey akad. RAMN prof. Sofronova G. A., prof. Aleksandrova M.V. [Extreme toxicology. Textbook edited by RAMS Academicians prof. Sofronov G.A., prof. Alexandrov M.V.], 2012, p. 254 [in Russian].

19. Yurydychna entsyklopediya: V 6 t. [Legal encyclopedia: In 6 v.] (2001) / Redkol.: Yu. S. Shemshuchenko (holova redkol.) [ta in.]. Kyiv: "Urk. Entsykl.”, V. 3, p. 792 [in Ukrainian]. 